\title{
Changing maladaptive beliefs among individuals with coronary heart disease using video information
}

\author{
Henndy Ginting, ${ }^{1 *}$ Gérard W. B. Näring, ${ }^{2}$ Eni Sabrine Becker, ${ }^{2}$ Pintoko Tedjokusumo ${ }^{3}$ \\ ${ }^{1}$ School of Business and Management, Institut Teknologi Bandung, Bandung - Indonesia, ${ }^{2}$ Behavioural \\ Science Institute, Radboud University, Nijmegen - the Netherlands, ${ }^{3}$ Cardiac Center, Bandung Advent Hospital, \\ Bandung - Indonesia
}

\begin{abstract}
Many individuals with coronary heart disease (CHD) have erroneous beliefs about the condition, which in turn increases anxiety and depression. Providing information and facts about CHD through video may be able to correct the wrong conceptions of individuals about their disease. A total of 150 individuals with CHD at Hasan Sadikin Hospital, Bandung, Indonesia (male $=65 \%$, female $=35 \%$ ) were divided into a control group and two experimental groups, with a quasi-experimental before-after design. The participants completed the York Cardiac Beliefs questionnaire at the start of the measurement, immediately after watching the video (time 1), and again after watching the video six times over a two week period (time 2). Beck Anxiety Inventory and Beck Depression Inventory-II questionnaires were also completed by participants at the beginning of the experiment and at time 2 . The repeated measures ANOVA analysis showed a significant decrease in both experimental groups in terms of wrong beliefs about CHD $(\mathrm{t}=8.68 \& 8.69, \mathrm{p}<.01)$, anxiety $(\mathrm{p}<.01)$, and depression $(\mathrm{t}=8.17 \& 7.76, \mathrm{p}<.01)$. Watching videos giving facts and information about CHD can therefore correct erroneous beliefs about CHD, and reduce levels of anxiety and depression in individuals suffering from the disease.
\end{abstract}

Keywords: anxiety; CHD; depression; maladaptive beliefs; video information

\begin{abstract}
Abstrak: Banyak individu dengan penyakit jantung koroner (PJK) memiliki keyakinan yang keliru tentang PJK sehingga pada akhirnya meningkatkan kecemasan dan depresi. Pemberian informasi dan fakta tentang PJK melalui video mungkin dapat memperbaiki konsepsi yang salah pada individu dengan PJK tentang penyakitnya. Sebanyak 150 individu dengan PJK di Rumah Sakit Hasan Sadikin, Bandung, Indonesia (Laki-laki $=65 \%$, Perempuan $=35 \%$ ) dibagi ke dalam kelompok kontrol dan dua kelompok eksperimental dengan desain before-after quasi experimental. Partisipan mengisi kuesioner York Cardiac Beliefs pada awal pengukuran, sesaat setelah menonton video (waktu 1), dan setelah menonton video enam kali selama dua minggu (waktu 2). Kuesioner Beck Anxiety Inventory dan Beck Depression Inventory II juga dikerjakan oleh partisipan pada saat awal eksperimen dan di waktu 2. Analisis dengan repeated measures ANOVA menunjukkan penurunan signifikan pada kedua kelompok eksperimen dalam hal keyakinan yang keliru tentang PJK $(\mathrm{t}=8,68 \& 8,69, \mathrm{p}<0,01)$, kecemasan $(\mathrm{p}<0,01)$, dan depresi $(\mathrm{t}=8,17 \& 7,76, \mathrm{p}<0,01)$. Dengan menonton video tentang fakta dan informasi tentang PJK dapat memperbaiki keyakinan yang keliru tentang PJK, serta mengurangi level kecemasan dan depresi pada individu dengan PJK.
\end{abstract}

Kata Kunci: kecemasan; PJK; depresi; keyakinan keliru; video informasi

\footnotetext{
*Corresponding Author: Henndy Ginting (henndy.ginting@sbm-itb.ac.id), School of Business and Management, Institut Teknologi Bandung, Jl. Ganesa No.10, Lb. Siliwangi, Kecamatan Coblong, Kota Bandung 40132 - Indonesia.
} 


\section{Introduction}

The Indonesian health ministry reported in 2017 that more than four million Indonesians were suffering from coronary heart disease (Kementerian Kesehatan Republik Indonesia, 2018) . The number of cardiologists in Indonesia was 1,321 in 2021, most of whom were practising on Java Island (Inaheart, 2021). Medical doctors in Indonesia tend to focus on medication or suggest medical procedures to CHD patients, but overlook patients' psychosocial experiences (Dit. Pelayanan Kafarmasian, 2013). Consequently, individuals with CHD have limited access to comprehensive information about the disease.

Such limited access may create misinterpretation of facts and maladaptive beliefs about the disease. These beliefs refer to the incorrect ways individuals represent the threats related to their disease. They may tend to believe more in the myths, rather than the truth about CHD (Furze, 2007; Koerner et al., 2015), which may increase the levels of anxiety and depression among patients. Symptoms of anxiety and depression are known worldwide to be important risk factors for mortality, myocardial infarction (MI), and unstable angina in CHD patients (Bunker et al., 2003; Kubzansky et al., 2006; Sirois \& Burg, 2003).

There is considerable evidence to show that providing the information is a successful way of reducing anxiety (Adwas et al., 2019; LudwickRosenthal \& Neufeld, 1988; Mahler et al., 1993; Mahler \& Kulik, 2002). Comprehensive information about the disease enables people to cope with it more quickly. Patient education programs that increase their knowledge and adaptive beliefs about a disease can reduce anxiety, increase patients' feelings of purpose and meaning in life, and minimize depressive symp- toms (Koerner et al., 2015; Morrison \& Bennett, 2006; Taylor, 2006). This relation is explained in Leventhal's theory, which argues that people build cognitive representations of their illness which engender an emotional response (Furze et al., 2009; Leventhal et al., 1997).

Information about diseases is usually provided using various media, such as written educational materials (e.g., pamphlets or in booklet form); individual discussions with healthcare professionals; and videos for home viewing that such professionals facilitate (Latif et al., 2016; Rankin et al., 2005). Patient education programs using video are an effective method of information dissemination. Video-based education in cancer patients led to a significant increase in knowledge and decreased anxiety (Ghisi et al., 2014; Gysels \& Higginson, 2007; Orringer et al., 2005).

Several studies about the impact of providing information using videos have been conducted on CHD patients prior to cardiac medical procedures (Blickem et al., 2011; Goulding, Furze, \& Birks, 2010; Nahid, Abbas, \& Majid, 2011). Most of the information given in these studies concerned medical procedures and their consequences. There is also a trend of using video on the internet and smartphones for psychosocial interventions in cardiac patients. Most of these are available for patients who have undergone surgical intervention. Still, little research has been conducted on examining the effects of such information on cardiac misconceptions amongst individuals with stable CHD (Foxwell et al., 2013). Therefore further high-quality research to establish effective interventions to dispel cardiac misconceptions and reduce psychosocial risk factors in such individuals is needed (Ghisi et al., 2014; Goulding et al., 2010). 
The content of the video was designed to be non-threatening and positively slanted to increase patient confidence (Mahler \& Kulik, 1998), with statements such as "even with heart disease, life could be better than before". Moreover, a CHD survivor involved in the video was expected to be a role model for the patients, and two cardiologists who also engaged as actors in the video were expected to be change agents, with the authority to give information (Bartholomew et al., 2011). Additionally, allowing participants to ask questions and to view the video more often over several days was thought might increase the intervention effectiveness (Bartholomew et al., 2011), since these opportunities would first activate patients' curiosity, and consequently they would start to search for more information, both from repeated viewings of the video and from asking questions to a medical professional (Leventhal et al., 1997; Sørlie et al., 2007). Therefore, the first hypothesis of this study is that obtaining information from videos will reduce maladaptive beliefs about the disease in individuals with CHD. The second hypothesis is that giving these individuals the chance to ask questions and to view the video more often will further reduce maladaptive beliefs about their disease. The third hypothesis is that individuals with CHD who have viewed the video will have lower anxiety and depression levels. Finally, the fourth hypothesis is that if these individuals have also had the chance to ask questions, this will also lead to lower anxiety and depression levels.

\section{Method}

\section{Research Design}

The study used a before-after quasiexperimental design to test the immediate and lasting effects of acquiring information from the video about CHD on maladaptive beliefs. In addition, the effects of the video on the levels of depression and anxiety participants were also measured. Five experimenters, all graduate students from the Faculty of Psychology, were trained as data collectors. They were unaware of the hypotheses and only had general information about the study. They were taught how to approach participants, administer questionnaires, give instructions, and to play a video. In addition, it was also emphasized that they should ask for permission and agreement from the patients who joined the experiment. Therefore, the data collected was based on the consent of the patients.

In particular, the sampling technique was a non-randomized controlled trial (non-RCT) which was not free from selection bias. Non-RCT study is still considered reliable since it was theoretically supported by a randomized study or many nonrandomized studies and had an adequate sample size (Ferriter \& Huband, 2005; Stanley, 2007). Moreover, all the participants in this study had social health insurance, government-funded insurance for lower social-economic citizens, which only allows public facilities for primary care (Chee et al., 2009; Dirjen Kesehatan Masyarakat, 2010). It indicates that the participants were comparable socioeconomically.

\section{Research Participants}

Contact information and confirmation of CHD diagnosis of $350 \mathrm{CHD}$ outpatients were obtained from nurses authorized to access patients' medical records in the outpatient cardiology clinic in Dr. Hasan Sadikin General Hospital, Bandung, Indonesia. Access to the hospital to conduct the study was obtained through the hospital's ethics committee. The data collected from the participants in the experimental group took place 
in their homes and Maranatha Christian University (MCU), Bandung, Indonesia, whereas that of the control group was made in the cardiology clinic of the hospital. Consequently, geographical criteria were used to limit travel time and cost.

Based on the list of participants, each experimenter was provided with a list of 70 to be contacted by telephone. Once the experimenters had finished calling people from the list, they made another attempt to call those who could not be contacted at the first attempt. Finally, a total of 168 individuals with CHD agreed to participate (see Figure 1). They were between 40 and 70 years of age, able to give written informed consent; had no immediate life-threatening condition; had no non-CHD related chronic illnesses; and were able to read and write Bahasa Indonesia (the country's official language). Cardiologists diagnosed them with CHD using at least one of the various diagnostic methods, such as coronary angiography, echocardiography, treadmills, and electro-cardiograms.

\section{Measuring Instruments}

The Beck Anxiety Inventory (BAI) (Beck \& Steer, 1993), which consists of 21 items, was used to measure patients' anxiety. Each response on the BAI is scored on a scale from 0 (no anxiety) to 3 (severe anxiety), with total scores ranging from 0 to 63 . Higher scores on the scale reflect an increased anxiety level. The Indonesian version of the BAI showed a high internal consistency $(\alpha=$ 94). The York Cardiac Beliefs Questionnaire (YCBQ) was also employed to measure the maladaptive beliefs about the disease (Furze et al., 2005). The YCBQ is the latest version of a 22-item questionnaire that can be used to measure CHD patients' maladaptive beliefs about their disease.
Each response in the YCBQ is scored on a scale from 0 (strongly agree) to 4 (strongly disagree); total scores therefore range from 0 to 88 . The Indonesian version of the YCBQ showed an adequate internal consistency $(\alpha=.89)$

The Beck Depression Inventory-II (BDI-II). Depression was measured with the BDI-II, a 21item self-administered questionnaire, with each response scored on a scale from 0 (no depression) to 3 (severe depression) and total scores ranging from 0 to 63 (Beck et al., 1996). The Indonesian version of the BDI-II is a valid measure of depression, both in the Indonesian general population and in CHD patients (Ginting, Näring, van der Veld, et al., 2013).

\section{Research Procedures}

For the study, a video containing information about the facts and the common misconceptions about CHD was developed. The video was entitled: "Mitos dan Fakta tentang Penyakit Jantung Koroner", which translates as "The Myths and the Truth about Coronary Heart Disease". The view on cardiac misconceptions (Furze, 2007) was adopted to develop the intervention and write the video scenario. The 25-minute video features 22 items, each covering particular myths and truths about CHD (e.g., The myth: Your heart is like a battery; The truth: Exercises can strengthen the heart muscle). The items were presented in several scenes, including a description by a narrator, a series of interviews with two cardiologists conducted by a clinical psychologist, and a testimonial talk by a patient diagnosed with CHD seven years ago. The interview with the two cardiologists comprises almost $60 \%$ of the video. The video scenario was approved by the ethics committee of the hospital where the study was conducted. 
The video was designed to be nonthreatening by using neutral or positive scenes and avoiding the color red (related to blood) and heart threatening-related pictures (Ginting, Näring, \& Becker, 2013). In addition to the main topic (22 items concerning the myths and the truths about CHD), the video provided other facts about CHD, its incidence, risk factors, and various types of treatment. The video's script and its visualization were evaluated by a panel of experts consisting of three senior cardiologists, two clinical psychologists who provided counseling to CHD patients, and one audio-visual consultant. Comments from patients and evaluations from the panel of experts were used for the final editing.

A questionnaire consisting of ten true or false questions about the general information is given on the video was created to ensure that participants watched the video at home and properly understood the provided information. The questions were about observable subjects or people featuring in the video (e.g., True or False The cardiologists in the video are men). All the items in the questionnaire proved to be easy, with their difficulty index ranging from .79 to .91 (Backhoff et al., 2000).

After establishing a good rapport with the participants and obtaining written informed consent, the experimenters made baseline measurements by administering a brief demographic form, the YCBQ, the BAI, and the BDI-II. Next, the participants in the experimental groups viewed the video, whereas those in the CG waited for 25 minutes and were offered food and drinks. Participants in EG1 watched the video individually, without being given opportunity to ask questions. Participants in EG2 watched the video for the first time in a group of five participants and had the opportunity to ask a general practitioner some questions. Furthermore, the experimenters conducted the second YCBQ measurement.

From the baseline to the second measurement, the experimental procedure took about 90 minutes to complete. For EG1, the procedure was conducted in the participants' homes, whereas for EG2 it was conducted in a room at MCU. In addition, the procedure conducted individually in the cardiology clinic at the hospital for the participants in the CG.

After the second measurement, those in the experimental groups received a compact disc of the video to view at home three times a week for two weeks. The participants in EG2 were free to contact a hotline number or send a short message (between 8 am and $8 \mathrm{pm}$ ) during the experiment time if they wanted to ask questions about the video. On average, our team and the general practitioner received two questions a day in the first week and no questions in the second week. Additionally, the experimenters approached every participant twice (on the third and the tenth days of the experiment period) by telephone to remind those in the experimental groups of the number of times they had to watch the video. Compliance was checked when the final measurement was conducted two weeks after the second measurement.

After the participants in the experimental groups had viewed the video at home during the two-week period, the final measurement was made. This consisted of the questionnaire about the general information given by the video, the YCBQ, the BAI, and the BDI-II. To complete these measures, the participants in EG1 and EG2 were visited in their homes, whereas those in the CG were invited to the clinic. The latter were offered the compact disc of the video at the end of the 
study. The experimental procedure and flow of the participants through the study is visualized in Figure 1.

To test whether viewing the video would reduce maladaptive beliefs about the disease in individuals with CHD, group differences in such beliefs were analysed across time. The analysis was conducted using a mixed-factor (3 [Times] $\mathrm{x}$ 3 [Groups])-repeated measure analysis of covariance (ANCOVA), with the length of formal education entered as a covariate.

\section{Figure 1}

Stages in the Experimental Procedure and Flow of the Participants through the Study

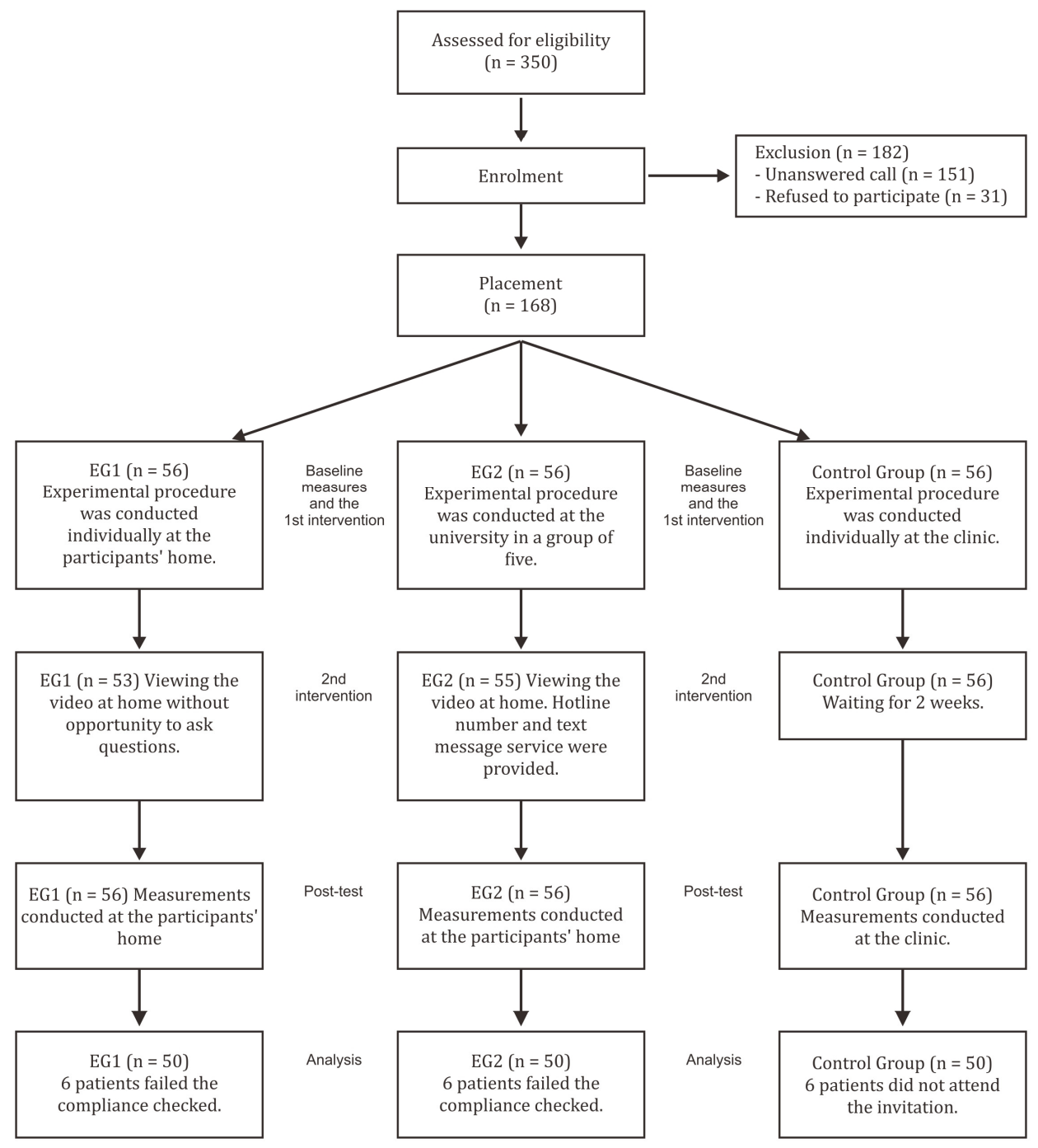


In the ANCOVA, the within-subject factors included three levels of time (baseline, time 1, and time 2), while the between-subject factors contained three group levels. This analysis was followed by simple contrasts in a multivariate analysis of covariance (MANCOVA), with the three group levels entered as independent variables; the maladaptive beliefs in baseline, time 1 , and time 2 as dependent variables; and the length of formal education as a covariate. Besides contrasting the beliefs in the CG with EG1 and EG2, these contrasts also allowed us to test whether the group with an opportunity to ask questions (EG2) would have lower maladaptive beliefs than that without such an opportunity (EG1). A paired-samples t-test was conducted to compare them between time 1 and time 2 in each group to test whether viewing the video more often would reduce the beliefs.

Another mixed-factor (2[Times] x 3 [Groups]) -repeated measure ANCOVA was used to examine group differences in anxiety and depression levels at the baseline and time 2. A MANCOVA also followed this analysis. The three group levels entered as independent variables; maladaptive beliefs in the baseline and time 2 as dependent variables; and the length of formal education as a covariate. Simple contrasts in this MANCOVA allowed us to test whether EG1 and EG2 had lower anxiety and depression levels than the CG after the intervention and whether EG2 had lower anxiety and depression levels than EG1. Additionally, one-way ANOVA and chi-square tests were conducted to compare the demographic and clinical characteristics of the groups. All the statistical analyses were conducted using SPSS 19 (IBM).

\section{Results}

In total, 150 participants (50 participants in each group) completed the experiment and were included in the analyses. Table 1 shows the demographic and clinical characteristics of each group.

\section{Table 1}

Demographic and Clinical Characteristics

\begin{tabular}{llll}
\hline \multirow{2}{*}{ Variable } & \multicolumn{2}{l}{ Mean (Standard Deviation) or $\%$} \\
\cline { 2 - 3 } & CG $(N=50)$ & EG1 $(N=50)$ & EG2 $(N=50)$ \\
\hline Demographic & & & \\
Gender (male) & $66.0 \%$ & $64.0 \%$ & $66.0 \%$ \\
Age (years) & $57.6(7.67)$ & $57.02(6.88)$ & $59.16(5.84)$ \\
Length of education (years) & $12.96(2.67)$ & $14.56(1.89)$ & $13.88(.199)$ \\
Religion (Islam) & $76.0 \%$ & $82.0 \%$ & $84.0 \%$ \\
Ethnicity (Javanese) & $66.0 \%$ & $66.0 \%$ & $56.0 \%$ \\
Clinical & & & \\
Diagnosis time (<3 years) & $70.0 \%$ & $80.0 \%$ & $68.0 \%$ \\
MI experience & $34.0 \%$ & $40.0 \%$ & $26.0 \%$ \\
PCI (Stenting) & $38.0 \%$ & $30.0 \%$ & $32.0 \%$ \\
CABG surgery & $12.0 \%$ & $2.0 \%$ & $10.0 \%$ \\
Medication (> 1 types) & $66.0 \%$ & $76.0 \%$ & $78.0 \%$ \\
\hline
\end{tabular}

Note: $\mathrm{CG}=$ Control Group; EG1 = Experimental Group without the opportunity to ask questions;

EG2 = Experimental Group with the opportunity to ask questions; Diagnostic time = Time since first diagnosis; $\mathrm{PCI}=$ Percutaneous Coronary Intervention; $\mathrm{CABG}=$ Coronary Artery Bypass Grafting; Medications = types of blood thinner, beta-blockers, calcium channel blockers, nitrates, and cholesterol medication. 
Figure 2

Means of the Maladaptive Beliefs about Heart Disease (YCQB scores) over Time in the Three Groups

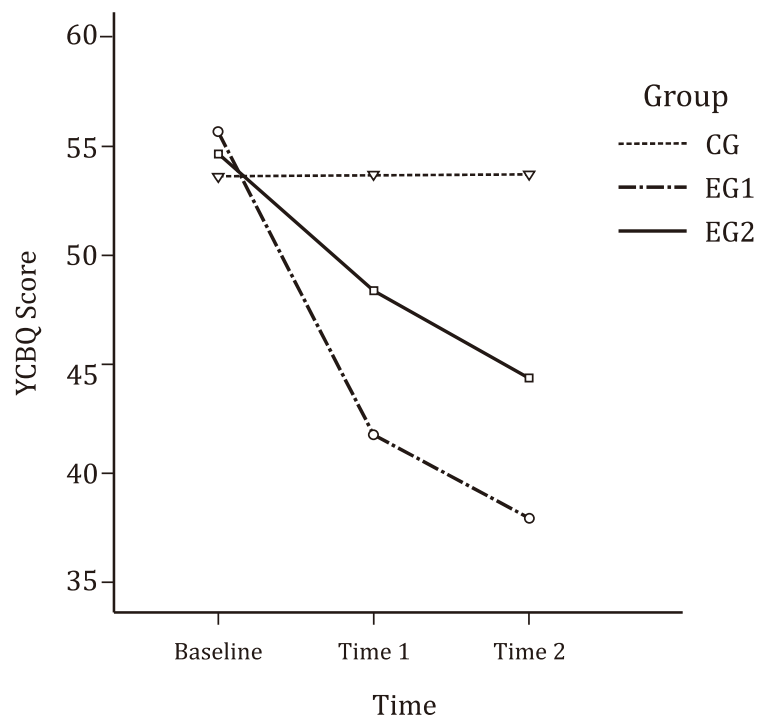

The one-way ANOVA revealed a significant difference between EG1, EG2, and CG regarding educational level. At the same time, the Chisquare tests indicated no significant differences between the three groups regarding medication and treatment procedures, gender, ethnicity, or religion.

Figure 2 shows the immediate effect (time 1) and that of two weeks (time 2) of watching the video on the participants' maladaptive beliefs about their disease (hereafter referred to as maladaptive beliefs) across groups. The ANCOVA yielded significant effects of time, $F(2,292)=5.31$, $\mathrm{p}=.005, \eta^{2}=.014$ and group, $\mathrm{F}(2,146)=19.44, \mathrm{p}<$ $.001, \eta^{2}=.10$. In the ANCOVA, the interaction of group by time was also significant, $\mathrm{F}(4,292)=$ $57.38, \mathrm{p}<.001, \eta^{2}=.58$. These results suggest that the differences between groups in maladaptive beliefs were significant between times.
The MANCOVA showed significant differences in maladaptive beliefs between the groups at time $1, \mathrm{~F}(2,146)=30.99, \mathrm{p}<.001, \eta^{2}=$ .30 , and time $2, \mathrm{~F}(2,146)=60.46, \mathrm{p}<.001, \eta^{2}=$ .45 , but not at the baseline, $F(2,146)=1.08, p=$ $.341, \eta^{2}=.007$.

Simple contrasts in the MANCOVA revealed significant differences in maladaptive beliefs at time 1 between the $C G(M=53.76 ; S D=5.85)$ and both EG1 (M = 48.36; SD = 7. 75), $\mathrm{p}=.001$, and EG2 ( $M=41.76$; $S D=8.60), p<.001$. These contrasts also revealed significant differences in maladaptive beliefs at time 2 between the $\mathrm{CG}(\mathrm{M}=$ 53.70; $\mathrm{SD}=6.03)$ and both EG1 ( $\mathrm{M}=44.40$; $\mathrm{SD}=$ 7.43), $\mathrm{p}<.001$, and EG2 ( $\mathrm{M}=37.96 ; \mathrm{SD}=7.56), \mathrm{p}$ $<.001$. There were no significant differences in maladaptive beliefs at the baseline between the $\mathrm{CG}(\mathrm{M}=53.48 ; \mathrm{SD}=7.58)$, EG1 ( $\mathrm{M}=54.74 ; \mathrm{SD}=$ 6.13), and EG2 ( $\mathrm{M}=54.72 ; \mathrm{SD}=7.37), \mathrm{p}>.05$. These results suggest that after viewing the video, 
participants in both EG1 and EG2 had fewer maladaptive beliefs than those in the CG. The contrasts in the MANCOVA also reveal significant differences in maladaptive beliefs between EG1 and EG2, both at time $1(\mathrm{p}<.001)$ and time $2(\mathrm{p}<$ .001). These results suggest that participants who viewed the video and had a chance to ask questions showed fewer maladaptive beliefs than those who did not have a chance to ask questions.

A paired samples t-test was conducted to compare maladaptive beliefs between time 1 and time 2 in each group. The analysis showed significant differences in beliefs between time 1 and time 2 , both in EG1, $\mathrm{t}(49)=8.68, \mathrm{p}<.001$, and $\mathrm{EG} 2, \mathrm{t}(49)=8.69, \mathrm{p}<.001$, but not in the CG, $\mathrm{t}(49)$ $=.31, \mathrm{p}=.757$. The analyses indicate that maladaptive beliefs were significantly reduced after two weeks of viewing the video in both groups (with and without the chance to ask questions).

The effects of viewing the video on the levels of anxiety and depression could be explained in the following results. The ANCOVA showed a significant effect of time on anxiety, $F(1,146)=$ $6.54, p=.012, \eta^{2}=.035$, but not on depression, $\mathrm{F}(1,146)=.14, \mathrm{p}=.707, \eta^{2}=.0007$. Most importantly, the interactions of group by time were significant for anxiety, $\mathrm{F}(2,146)=16.65, \mathrm{p}<$ $0.001, \eta^{2}=.18$, and for depression $\mathrm{F}(2,146)=$ $15.49, p<0.001, \eta^{2}=.10$. The test of the betweensubject effects indicated significant differences between the groups related to anxiety, $\mathrm{F}(2,146)=$ 13.37, $\mathrm{p}<.001, \eta^{2}=.14$, and depression, $\mathrm{F}(2,146)$ $=10.54, \mathrm{p}<0.001, \eta^{2}=.12$. These analyses indicate that the levels of anxiety and depression were different between the groups across time.

The MANCOVA showed a significant difference in the anxiety level between the groups at time $2, \mathrm{~F}(2,146)=31.45, \mathrm{p}<.001, \eta^{2}=.13$, but not at the baseline, $F(2,146)=1.86, p=.160, \eta^{2}=$ .025. Simple contrasts in the MANCOVA revealed significant differences in anxiety at time 2 between the $\mathrm{CG}(\mathrm{M}=13.04 ; \mathrm{SD}=7.28)$ and both EG1 ( $M=5.08 ; S D=5.27), p=.001$, and EG2 ( $M=$ 4.78; $\mathrm{SD}=3.91), \mathrm{p}<.001$. There were no significant differences in anxiety at the baseline between the $\mathrm{CG}(\mathrm{M}=15.26$; $\mathrm{SD}=6.52)$, EG1 ( $\mathrm{M}=$ 12.30; $\mathrm{SD}=6.93), \mathrm{p}=.06$, and EG2 (M = 13.69; SD $=6.81), p=.25$. These results suggest that after viewing the video, the participants in both EG1 and EG2 had lower anxiety levels compared to those in the CG. There was no significant difference in the anxiety level between EG1 and EG2, either at the baseline $(p=.414)$ or time $2(p=$ .784). These results suggest that the anxiety levels in participants who viewed the video and had a chance to ask questions were no different from those who did not have a chance to ask questions.

Another MANCOVA showed a significant difference in depression level between groups at the baseline, $F(2,146)=3.22, p=.043, \eta^{2}=.012$, and at time $2, F(2,146)=17.40, p<.001, \eta^{2}=.092$. Simple contrasts in this MANCOVA revealed significant differences in depression at the baseline between the CG $(M=12.06 ; S D=6.44)$ and both EG1 ( $M=9.06 ; S D=6.43), p=.020$, and EG2 $(M=9.50 ; S D=5.72), p=.042$. These contrasts also revealed significant differences in depression at time 2 between the CG $(M=13.04$; $S D=7.28)$ and both EG1 ( $M=5.36 ; S D=7.17), p<$ .001 , and EG2 $(M=5.36 ; S D=6.50), p<.001$. There were no significant differences in depression between EG1 and EG2 either at the baseline ( $p=.713)$ or at time $2(p=.924)$. These results suggest that depression levels in the participants who viewed the video and had a 
chance to ask questions (EG2) were no different from those who did not have a chance to ask questions (EG1).

Due to the significant difference in depression levels between groups at the baseline, a paired samples t-test was conducted to compare the levels between the baseline and time 2 in each group. This analysis showed significant differences in the level of depression between the baseline and time 2 in EG1, t(49) = 8.17, p<.001, and EG2, $\mathrm{t}(49)=7.76, \mathrm{p}<.001$, but not in the CG, $\mathrm{t}(49)=-$ $1.08, \mathrm{p}=.282$. The analysis indicates that depression levels were significantly reduced after two weeks of viewing the video in both experimental groups (EG1 and EG2), but not in the CG.

\section{Discussion}

The study has tested the immediate as well as the lasting effects of providing video information on beliefs about the disease in individuals with CHD. Additionally, it has examined the effect of this intervention on reducing anxiety and depression levels in sufferers. The results show that providing information about the facts and misconceptions of heart disease using professionally developed video information proves to be an effective method of changing maladaptive beliefs about the disease and reducing levels of anxiety and depression. The video used in the research contained factual information about CHD, which was somewhat optimistically slanted and excluded negative information about the disease. Consequently, the information in the video aimed to encourage patients to have positive expectations of their disease (Bandura, 1993; Bartholomew et al., 2011).

Maladaptive beliefs were the first target of the video intervention. According to the illness representation theory (Leventhal et al., 1997), maladaptive beliefs are comparable with irrational aspects of patients' mental representation of threats to their health. Video intervention seems to be an effective way of activating patients' curiosity and enhancing their knowledge, which in turn could correct maladaptive beliefs. As active problem solvers, patients select and elaborate information to manage threats and change their previous beliefs when they obtain disconfirming feedback (Leventhal et al., 1997). Giving opportunities to patients to ask questions and watch the video more often will help them elaborate information more. These opportunities may also be especially helpful because individuals with CHD have been indicated to be deficit in executive functioning (Ginting, Näring, \& Becker, 2013).

Our findings are in line with the previous works of Mahler and Kulik (1998, 2002), which were conducted with coronary bypass surgery patients and their spouses using mastery and coping tape conditions. In the mastery tape condition, patients were provided with more optimistically-slanted information, whereas in the coping tape condition, they were given information about the possible problems of the disease. Compared to the latter, those in the mastery tape condition, who were encouraged by positive expectations about the disease, reported fewer complaints related to their disease (Mahler \& Kulik, 2002).

Our finding that watching video information about CHD results in more adaptive beliefs about the disease also corroborates the findings of Furze et al. (2009). Their educational program used information about the truths and myths about heart disease as a core component. Compared to 
the patients receiving nurse counseling alone, the program used by Furze et al. significantly reduced misconceptions about heart disease in patients undergoing bypass surgery. Our finding adds to the body of knowledge, suggesting that providing CHD patients with appropriate information about their disease can change their related maladaptive beliefs (Bartholomew et al., 2011; Morrison \& Bennett, 2006). In order to modify incorrect knowledge about the disease, delivering well-validated information about the facts and common misconceptions about CHD (Furze, 2007; Furze et al., 2005), were most likely to be important keys to the effect of our video intervention to change maladaptive beliefs about the disease (Blickem et al., 2011).

Our study also provides evidence that delivering information about CHD (e.g., most people who have had one heart attack do not necessarily have another) to sufferers can lead them to change their maladaptive beliefs about the disease. Such video information also reduces the level of anxiety and depression. Assigning a professional cardiac nurse as a consultant to whom patients could ask questions about the information in the video and who could advise them to watch the video more often will result in greater changes in the maladaptive beliefs of individuals with CHD.

The study suggests that there was no difference in the effect of watching the video between patients given the opportunity to ask questions and those without the opportunity to do so. However, the results also show that viewing the video more frequently is better than just watching it just once with regards to changing the maladaptive beliefs of individuals with CHD about their disease. Allowing patients to ask questions also enhanced their positive beliefs about their disease. These findings confirmed our expectation that the video is an effective homeand hospital-based intervention program which could adjust maladaptive beliefs, and reduce the levels of anxiety and depression in CHD patients.

The study had several limitations. First, the participants were CHD patients with varying disease severity, and this could have affected the results. Differences in the capacity of heart function which could not be identified, for example, could affect the differences in anxiety and depression. This specific information could not be accessed from patients' medical records as they are confidential. Second, long-term follow-up measurements are needed to evaluate whether the effect of the video persists over time, beyond the two weeks measured in the study. Third, the geographical sampling strategy that was used undoubtedly minimized the costs and travel needs, but with an unintended consequence, in that the length of education, which was significantly different between groups, and other possible differences (e.g., available support, usual care) might have created sampling bias. However, in theoretical terms, the results of the study can still be considered reliable since they were confirmed by a randomized study (Goulding et al,, 2010). In addition, the sample size was sufficient and the participants were equal in socioeconomic status (Ferriter \& Huband, 2005; Stanley, 2007). Moreover, a statistical solution was adopted by including education level as a covariate in the analyses. Future studies that are better funded may wish to adopt a truly random sampling strategy.

\section{Conclusion}

The study makes several practical and specific contributions. The findings confirm that 
video is an effective home-based intervention program that can adjust maladaptive beliefs and reduce anxiety and depression in individuals with CHD. It is essential for patients who have limited access to healthcare professionals. In addition, the video intervention is convenient for individuals with CHD since they can watch the video at home together with their significant persons and repeat this as often as desired. In addition, the video can also be used in a hospital setting to complement written and verbal information. Moreover, given the cultural problem that Indonesian patients tend to take on a lower hierarchical position in the patient-doctor dyad and may be afraid to ask detailed questions about the disease, using the video will help to ensure that patients receive at least some appropriate information about CHD. Furthermore, the unfavorable cardiologist-patient ratio in Indonesia means patient education using the video for individuals with CHD is of the utmost importance, and should be a key component in addressing patient concerns. Finally, the video could save patients' time in obtaining appropriate information, and from an economic perspective, it is a significant way of reducing healthcare costs, especially in Indonesia.[]

\section{References}

Adwas, A. A., Jbireal, J. M., \& Azab, A. E. (2019). Anxiety: Insights into signs, symptoms, etiology, pathophysiology, and treatment. East African Scholars Journal of Medical Sciences, 2(10), 80-91.

Backhoff, E., Larrazolo, N., \& Rosas, M. (2000). The level of difficulty and discrimination power of the basic knowledge and skills examination (EXHCOBA). Revista Electrónica de Investigación Educativa, 2(1), 1-16.

Bandura, A. (1993). Perceived self-efficacy in cognitive development and functioning. Educational Psychologist, 28(2), 117-148. https://doi.org/10.1207/s15326985ep2802_3

Bartholomew, L. K., Parcel, G. S., Kok, G., Gottlieb, N. H., \& Fernandés, M. E. (2011). Planning health promotion program: An intervention mapping approach (3rd ed.). Jossey-Bass.

Beck, A., T., \& Steer, R., A. (1993). Beck anxiety inventory manual. Harcourt Brace and Company.

Beck, A. T., Steer, R. A., \& Brown, G. K. (1996). BDI-II, Beck Depression Inventory: Manual (2nd ed.). Harcour, Brace, \& Company.

Blickem, C., Bower, P., Protheroe, J., Kennedy, A., Vassilev, I., Sanders, C., Kirk, S., Chew-Graham, C., \& Rogers, A. (2011). The role of information in supporting self-care in vascular conditions: A conceptual and empirical review. Health \& Social Care in the Community, 19(5), 449-459. https://doi.org/10.1111/j.1365-2524.2010.00975.x

Bunker, S. J., Colquhoun, D. M., Esler, M. D., Hickie, I. B., Hunt, D., Jelinek, V. M., Oldenburg, B. F., Peach, H. G., Ruth, D., Tennant, C. C., \& Tonkin, A. M. (2003). "Stress" and coronary heart disease: Psychosocial risk factors. Medical Journal of Australia, 178(6), 272-276. https://doi.org/10.5694/j.1326-5377.2003.tb05193.x

Chee, G., Borowitz, M., \& Barraclough, A. (2009). Private sector health in Indonesia. USAID - Health Systems 20/20 project, Abt Associates Inc.

Dirjen Kesehatan Masyarakat. (2010). Pedoman pelaksanaan jaminan pemeliharaan kesehatan. Kemenkes RI. 
Dit. Pelayanan Kafarmasian. (2013, February 28). Pharmaceutical care untuk pasien penyakit jantung koroner: Fokus sindrom koroner akut (2006). falmakes.kemenkes.go.id; Direktorat Bina Kefarmasian dan Alat Kesehatan, Depkes. https:/farmalkes.kemkes.go.id/2013/02/ pharmaceutical-care-untuk-pasien-penyakit-jantung-koroner-fokus-syndrom-koroner-akut/

Ferriter, M., \& Huband, N. (2005). Does the non-randomized controlled study have a place in the systematic review? A pilot study. Criminal Behaviour and Mental Health, 15(2), 111-120. https://doi.org/10.1002/cbm.43

Foxwell, R., Morley, C., \& Frizelle, D. (2013). Illness perceptions, mood and quality of life: A systematic review of coronary heart disease patients. Journal of Psychosomatic Research, 75(3), 211-222. https://doi.org/10.1016/j.jpsychores.2013.05.003

Furze, G. (2007). Cardiac misconceptions - A problem in need of treatment? Practical Cardiovascular Risk Management, 5(1), 13-15.

Furze, G., Dumville, J. C., Miles, J. N. V., Irvine, K., Thompson, D. R., \& Lewin, R. J. P. (2009). "Prehabilitation" prior to CABG surgery improves physical functioning and depression. $\begin{array}{llll}\text { International Journal of 51-58. } & \end{array}$ https://doi.org/10.1016/j.ijcard.2008.06.001

Furze, G., Lewin, R. J. P., Murberg, T., Bull, P., \& Thompson, D. R. (2005). Does it matter what patients think? The relationship between changes in patients' beliefs about angina and their psychological and functional status. Journal of Psychosomatic Research, 59(5), 323-329. https://doi.org/10.1016/j.jpsychores.2005.06.071

Ghisi, G. L. de M., Abdallah, F., Grace, S. L., Thomas, S., \& Oh, P. (2014). A systematic review of patient education in cardiac patients: Do they increase knowledge and promote health behavior change? Patient Education and Counseling, 95(2), 160-174. https://doi.org/10.1016/j.pec.2014.01.012

Ginting, H., Näring, G., \& Becker, E. S. (2013). Attentional bias and anxiety in individuals with coronary heart disease. Psychology \& Health, 28(11), 1306-1322. https://doi.org/10.1080/08870446.2013.803554

Ginting, H., Näring, G., van der Veld, W. M., Srisayekti, W., \& Becker, E. S. (2013). Validating the Beck Depression Inventory-II in Indonesia's general population and coronary heart disease patients. International Journal of Clinical and Health Psychology, 13(3), 235-242. https://doi.org/10.1016/S1697-2600(13)70028-0

Goulding, L., Furze, G., \& Birks, Y. (2010). Randomized controlled trials of interventions to change maladaptive illness beliefs in people with coronary heart disease: Systematic review. Journal of Advanced Nursing, 66(5), 946-961. https://doi.org/10.1111/j.1365-2648.2010.05306.x

Gysels, M., \& Higginson, I. J. (2007). Interactive technologies and videotapes for patient education in cancer care: Systematic review and meta-analysis of randomised trials. Supportive Care in Cancer, 15(1), 7-20. https://doi.org/10.1007/s00520-006-0112-z

Inaheart. (2021). Find doctor: Find cardiologist in your area. Indonesian Heart Association. https://membersearch.inaheart.org/\#/

Jamshidi, N., Abbaszadeh, A., \& Kalyani, M. N. (2011). Effects of video information on anxiety, stress and depression of patients undergoing coronary angiography. Pakistan Journal of Medical Sciences, 25(2), 901-905.

Kementerian Kesehatan Republik Indonesia. (2018). Laporan nasional riset kesehatan dasar 2018. Lembaga Penerbit Balitbangkes. 
Koerner, N., Tallon, K., \& Kusec, A. (2015). Maladaptive core beliefs and their relation to generalized anxiety disorder. Cognitive Behaviour Therapy, 44(6), 441-455. https://doi.org/10.1080/16506073.2015.1042989

Kubzansky, L. D., Cole, S. R., Kawachi, I., Vokonas, P., \& Sparrow, D. (2006). Shared and unique contributions of anger, anxiety, and depression to coronary heart disease: A prospective study in the normative aging study. Annals of Behavioral Medicine, 31(1), 21-29. https://doi.org/10.1207/s15324796abm3101_5

Latif, S., Ahmed, I., Amin, M. S., Syed, I., \& Ahmed, N. (2016). Exploring the potential impact of health promotion videos as a low cost intervention to reduce health inequalities: A pilot before and after study on Bangladeshis in inner-city London. London Journal of Primary Care, 8(4), 66-71. https://doi.org/10.1080/17571472.2016.1208382

Leventhal, H., Benyamini, Y., Brownlee, S., Diefenbach, M., Leventhal, E. A., Patrick-Miller, L., \& Robitaille, C. (1997). Illness representations: Theoretical foundations. In K. J. Petrie \& J. A. Weinman (Eds.), Perceptions of health and illness: Current research and applications (pp. 19-47). Harwood Academic Publishers.

Ludwick-Rosenthal, R., \& Neufeld, R. W. (1988). Stress management during noxious medical procedures: An evaluative review of outcome studies. Psychological Bulletin, 104(3), 326-342. https://doi.org/10.1037/0033-2909.104.3.326

Mahler, H. I. M., \& Kulik, J. A. (1998). Effects of preparatory videotapes on self-efficacy beliefs and recovery from coronary bypass surgery. Annals of Behavioral Medicine, 20(1), 39-46. https://doi.org/10.1007/BF02893808

Mahler, H. I. M., \& Kulik, J. A. (2002). Effects of a videotape information intervention for spouses on spouse distress and patient recovery from surgery. Health Psychology: Official Journal of the Division of Health Psychology, American Psychological Association, 21(5), 427-437.

Mahler, H. I. M., Kulik, J. A., \& Hill, M. R. (1993). A preliminary report on the effects of videotape preparations for coronary artery bypass surgery on anxiety and self-efficacy: A simulation and validation with college students. Basic and Applied Social Psychology, 14(4), 437-453. https://doi.org/10.1207/s15324834basp1404_4

Morrison, V., \& Bennett, P. (2006). An introduction to health psychology. Pearson Education.

Orringer, J. S., Fendrick, A. M., Trask, P. C., Bichakjian, C. K., Schwartz, J. L., Wang, T. S., Karimipour, D. J., \& Johnson, T. M. (2005). The effects of a professionally produced videotape on education and anxiety/distress levels for patients with newly diagnosed melanoma: A randomized, prospective clinical trial. Journal of the American Academy of Dermatology, 53(2), 224-229. https://doi.org/10.1016/j.jaad.2005.03.061

Rankin, S. H., Stallings, K. D., \& London, F. (2005). Patient education in health and illness. Lippincott Williams \& Wilkins.

Sirois, B. C., \& Burg, M. M. (2003). Negative emotion and coronary heart disease. Behavior Modification, 27(1), 83-102. https://doi.org/10.1177/0145445502238695

Sørlie, T., Busund, R., Sexton, J., Sexton, H., \& Sørlie, D. (2007). Video information combined with individualized information sessions: Effects upon emotional well-being following coronary artery bypass surgery - A randomized trial. Patient Education and Counseling, 65(2), 180-188. https://doi.org/10.1016/j.pec.2006.07.006

Stanley, K. (2007). Design of randomized controlled trials. Circulation, 115(9), 1164-1169. https://doi.org/10.1161/circulationaha.105.594945

Taylor, E. S. (2006). Health psychology (6th ed.). McGraw-Hill. 